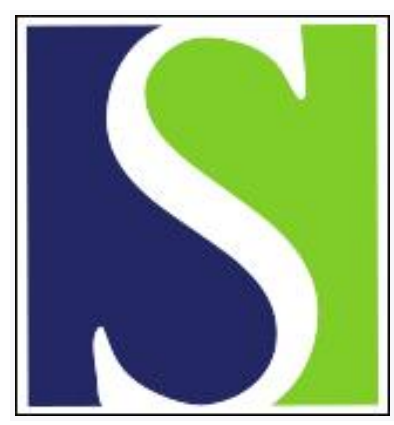

Scand J Work Environ Health 1993;19(3):137-147

https://doi.org/10.5271/sjweh.1489

Issue date: 01 Jun 1993

Lung cancer among butchers and slaughterhouse workers.

by Kristensen TS, Lynge $\mathrm{E}$

Affiliation: Institute of Social Medicine, University of Copenhagen, Panum Institute, Denmark.

This article in PubMed: www.ncbi.nlm.nih.gov/pubmed/8367690

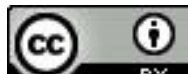




\title{
Lung cancer among butchers and slaughterhouse workers
}

\author{
by Tage S Kristensen, $\mathrm{PhD},{ }^{1}$ Elsebeth Lynge, $\mathrm{PhD}^{2}$
}

\begin{abstract}
KRISTENSEN TS, LYNGE E. Lung cancer among butchers and slaughterhouse workers. Scand $J$ Work Environ Health 1993;19:137-47. The following three questions are examined in this critical evaluation of the literature on lung cancer among butchers: (i) do butchers have an excess risk of lung cancer, (ii) if yes, is this excess possibly caused by exposures in the work environment, and (iii) if yes, what then are the possible etiologic exposures? It was concluded that butchers probably have an excess risk of lung cancer. This excess risk can be explained partly, but not entirely, by tobacco smoking. The following four possible etiologic exposures are introduced: human papilloma viruses, nitrite, incomplete combustion products, and fumes from meatpacking materials. Three of these possible explanatory factors (nitrite, combustion products and fumes from packing) are not, or only to a limited extent, substantiated by the empirical data. It was recommended that the hypothesis concerning human papilloma viruses and also the possible role of work stress be tested in future studies.
\end{abstract}

Key terms: combustion products, meat industry, meat packing, nitrite, papilloma virus, review, work stress.

Several brief reports from the early 1980 s $(1-9)$ and epidemiologic studies from the late 1980s (10-15) dealt with a possible excess risk of lung cancer among butchers. The objective of this article is to address the following questions: (i) does a comprehensive review of the literature support the existence of an excess risk of lung cancer among butchers; (ii) if yes, is this excess risk possibly caused by exposures in the work environment; and (iii) if yes, what then are the possible etiologic exposures? With respect to the last question, we have tried to assess the empirical evidence for an etiologic role of exposure to viruses, nitrite, incomplete combustion products, meatwrapping fumes, and work stress.

\section{Material and methods}

Various terms have been used for the study group, for example, butchers, slaughterhouse workers, abattoir workers, and meat industry workers. This review covers all slaughterhouse and meat industry workers (ie, workers engaged in slaughtering, cutting, processing, and packing meat products from pigs, cattle, sheep, and chickens if specified). We have used the term "butchers" to refer to the entire group. The original terms are used when the studies are quoted.

The design and analysis of the reviewed studies have been evaluated on the basis of a checklist with the following questions: (i) exposure measurement:

\footnotetext{
1 Institute of Social Medicine, University of Copenhagen, Panum Institute, Copenhagen, Denmark.

2 Danish Cancer Society, Danish Cancer Registry, Copenhagen, Denmark.
}

Reprint requests to: Dr TS Kristensen, Institute of Social Medicine, University of Copenhagen, Panum Institute, Blegdamsvej 3, DK-2200, Copenhagen N, Denmark. have the relevant exposures been measured in a valid and reliable way, and were the duration and intensity of the exposures measured; (ii) measurement of disease: has the incidence of or the mortality from lung cancer been registered in a valid and reliable way, and has lung cancer been registered in the same way among the exposed and unexposed persons; (iii) confounding: are the relevant confounders, especially tobacco smoking, known, and have they been controlled for in the study design or the analysis; (iv) selection: have the various selection mechanisms into and out of the occupation been elucidated and controlled for; (v) time dimension: has the time sequence between exposure and disease been sufficiently accounted for, and has the latency period been incorporated into the analysis?

\section{Results}

Brief reports from 1982-1983

A review of Danish occupational mortality data for 1970-1975 revealed an excess risk of lung cancer among butchers (1). Subsequently, Fox et al (2) reported excess risks of lung cancer among butchers in England and Wales, Denmark, and Sweden. The observed to expected ratios varied from 116 to 253 in eight study groups, and only the unskilled slaughterhouse workers in Denmark deviated from this pattern with a standardized mortality ratio (SMR) of 85 .

The report of Fox et al was followed by several letters to the Lancet on lung cancer in butchers. Griffith (3) drew attention to the fact that an excess lung cancer mortality had been found also among butchers in conjunction with the 1951 and 1961 censuses in England and Wales. Doerken \& Rehpenning (4) reported on a study from Hamburg, 1954-1966, in which butchers had a relative risk (RR) of lung can- 
cer of 2.4 when they were compared with bakers. Milham (5) presented death certificate data from Washington state, 1950-1979; he reported proportionate mortality ratios (PMR) close to 100 for lung cancer in butchers and meatcutters working inside and outside of slaughterhouses. Johnson \& Fischman (6) analyzed lung cancer deaths for members of the Meatcutters' Union in Baltimore and found a PMR of 154 for the period 1965-1980. Vena et al (7) were the first to present data controlled for smoking. The study covered patients admitted to the Roswell Park Memorial Institute in Buffalo, New York, in 1957-1965. White men ever employed in the meat industry had an odds ratio (OR) for lung cancer of 1.1 , which decreased to 1.0 when cigarette smoking was controlled for. Lynge et al (8) reported new findings for Danish butchers for 1975-1980. An excess lung cancer mortality was still observed among skilled butchers (SMR 151). Hogstedt et al (9) provided the last of the brief contributions. They found standardized incidence ratios (SIR) of 178 for Swedish butchers for the period 1961-1973, and 170 for the period 1974-1979. A Swedish national survey on smoking habits from 1963 indicated that butchers were more frequent smokers than the average of Swedish men, and therefore their lung cancer risk would presumably increase by $25 \%$.

Table 1 presents data from the brief reports. There are 19 independent estimates of the relative risk of lung cancer among butchers, of which 16 are above

Table 1. Populations, methods, and results concerning lung cancer among butchers and slaughterhouse workers in studies published in $1982-1983$. $^{\mathrm{a}}$ (SMR $=$ standardized mortality ratio, $\mathrm{PIR}=$ proportionate incidence ratio, $\mathrm{RR}=$ relative risk, $\mathrm{PMR}=$ proportionate mortality ratio, $\mathrm{OR}=$ odds ratio, SIR = standardized incidence ratio)

\begin{tabular}{|c|c|c|c|c|c|c|}
\hline Reference & $\begin{array}{l}\text { Occupational } \\
\text { group } \\
\text { studied }\end{array}$ & $\begin{array}{l}\text { Study } \\
\text { design }\end{array}$ & $\begin{array}{l}\text { Reference } \\
\text { group }\end{array}$ & $\begin{array}{l}\text { Number of } \\
\text { lung cancer } \\
\text { cases among } \\
\text { butchers or } \\
\text { slaughter- } \\
\text { house } \\
\text { workers }\end{array}$ & $\begin{array}{l}\text { Measure } \\
\text { of relative } \\
\text { incidence } \\
\text { or } \\
\text { mortality }\end{array}$ & $\begin{array}{c}\text { Relative } \\
\text { incidence } \\
\text { or } \\
\text { mortality }\end{array}$ \\
\hline \multicolumn{7}{|l|}{ Fox et al $1982(2)$} \\
\hline $\begin{array}{l}\text { National mortality } \\
\text { data, England and } \\
\text { Wales, 1970-1972 }\end{array}$ & $\begin{array}{l}\text { Male } \\
\text { butchers }\end{array}$ & $\begin{array}{l}\text { Cross- } \\
\text { sectional }\end{array}$ & $\begin{array}{l}\text { Total male } \\
\text { population, } \\
\text { adjusted for } \\
\text { social class } \\
\text { and age }\end{array}$ & 260 & SMR & 116 \\
\hline $\begin{array}{l}\text { National incidence } \\
\text { data, England and } \\
\text { Wales, 1966-1967 }\end{array}$ & $\begin{array}{l}\text { Male } \\
\text { butchers }\end{array}$ & $\begin{array}{l}\text { Cross- } \\
\text { sectional }\end{array}$ & $\begin{array}{l}\text { Other incident } \\
\text { cancer cases, } \\
\text { controlled for } \\
\text { age and gender }\end{array}$ & 286 & PIR & 127 \\
\hline $\begin{array}{l}\text { National incidence } \\
\text { data, England and } \\
\text { Wales, 1968-1970 }\end{array}$ & $\begin{array}{l}\text { Male } \\
\text { butchers }\end{array}$ & $\begin{array}{l}\text { Cross- } \\
\text { sectional }\end{array}$ & $\begin{array}{l}\text { Other incident } \\
\text { cancer cases, } \\
\text { controlled for } \\
\text { age and gender }\end{array}$ & 253 & PIR & 120 \\
\hline $\begin{array}{l}\text { Griffith } 1982 \text { (3) } \\
\text { National mortality } \\
\text { data, England and } \\
\text { Wales, 1959-63 }\end{array}$ & $\begin{array}{l}\text { Male butchers } \\
\text { and meatcutters }\end{array}$ & $\begin{array}{l}\text { Cross- } \\
\text { sectional }\end{array}$ & $\begin{array}{l}\text { Total male } \\
\text { population }\end{array}$ & 436 & SMR & 127 \\
\hline $\begin{array}{l}\text { National mortality } \\
\text { data, England and } \\
\text { Wales, } 1951\end{array}$ & $\begin{array}{l}\text { Male meat and } \\
\text { fish curers and } \\
\text { smokers }\end{array}$ & $\begin{array}{l}\text { Cross- } \\
\text { sectional }\end{array}$ & $\begin{array}{l}\text { Total male } \\
\text { population }\end{array}$ & 10 & SMR & 200 \\
\hline $\begin{array}{l}\text { National mortality } \\
\text { data, England and } \\
\text { Wales, } 1951\end{array}$ & $\begin{array}{l}\text { Male slaughter- } \\
\text { house workers }\end{array}$ & $\begin{array}{l}\text { Cross- } \\
\text { sectional }\end{array}$ & $\begin{array}{l}\text { Total male } \\
\text { population }\end{array}$ & 17 & SMR & 131 \\
\hline \multicolumn{7}{|l|}{$\begin{array}{l}\text { Doerken \& Rehpenning } \\
1982 \text { (4) }\end{array}$} \\
\hline $\begin{array}{l}\text { Study of incidence } \\
\text { and mortality among } \\
398 \text { butchers and } \\
399 \text { bakers from the } \\
\text { state of Hamburg, } \\
1954-1966\end{array}$ & Butchers & $\begin{array}{l}\text { Historical } \\
\text { prospective }\end{array}$ & $\begin{array}{l}\text { Bakers, } \\
\text { same age } \\
\text { distribution }\end{array}$ & 36 & RR & 2.4 \\
\hline \multicolumn{7}{|l|}{ Milham 1982 (5) } \\
\hline $\begin{array}{l}\text { Mortality study } \\
\text { in Washington } \\
\text { state, } 1950-1979\end{array}$ & $\begin{array}{l}\text { White male } \\
\text { butchers and } \\
\text { meatcutters in } \\
\text { slaughterhouses }\end{array}$ & $\begin{array}{l}\text { Cross- } \\
\text { sectional }\end{array}$ & $\begin{array}{l}\text { Other deaths } \\
\text { among white } \\
\text { males }\end{array}$ & 28 & PMR & 107 \\
\hline $\begin{array}{l}\text { Mortality study } \\
\text { in Washington state, } \\
1950-1979\end{array}$ & $\begin{array}{l}\text { White male } \\
\text { butchers and } \\
\text { meatcutters } \\
\text { outside } \\
\text { slaughterhouses }\end{array}$ & $\begin{array}{l}\text { Cross- } \\
\text { sectional }\end{array}$ & $\begin{array}{l}\text { Other deaths } \\
\text { among white } \\
\text { males }\end{array}$ & 89 & PMR & 97 \\
\hline
\end{tabular}


Table 1. Continued.

\begin{tabular}{|c|c|c|c|c|c|c|}
\hline Reference & $\begin{array}{l}\text { Occupational } \\
\text { group } \\
\text { studied }\end{array}$ & $\begin{array}{l}\text { Study } \\
\text { design }\end{array}$ & $\begin{array}{l}\text { Reference } \\
\text { group }\end{array}$ & $\begin{array}{l}\text { Number of } \\
\text { lung cancer } \\
\text { cases among } \\
\text { butchers or } \\
\text { slaughter- } \\
\text { house } \\
\text { workers }\end{array}$ & $\begin{array}{c}\text { Measure } \\
\text { of relative } \\
\text { incidence } \\
\text { or } \\
\text { mortality }\end{array}$ & $\begin{array}{c}\text { Relative } \\
\text { incidence } \\
\text { or } \\
\text { mortality }\end{array}$ \\
\hline
\end{tabular}

Johnson \& Fischman

$1982(6)$

Mortality study
of male members
of meatcutters
union. Baltimore,
1965-1980
Vena et al (1982) (7)
Hospital-based
study of white
male lung cancer
cases, Roswell Park
Memorial Institute,
1957-1965

Lynge et al 1983 (8)

National mortality

data, Denmark,

1970-1975

National mortality

data, Denmark,

1975-1980

National mortality

data, Denmark,

1970-1975

National mortality

data, Denmark,

1975-1980

National mortality

data, Denmark,

1970-1975

National mortality

data, Denmark,

1975-1980

National mortality

data, Denmark,

1970-1975

National mortality

data, Denmark,

1975-1980

Male union
members

$\begin{array}{ll}\text { Historical } & \begin{array}{l}\text { United States } \\ \text { prospective }\end{array} \\ & \begin{array}{l}\text { white males, } \\ \text { controlled for } \\ \text { age }\end{array}\end{array}$

27

PMR

154

$\begin{array}{ll}\text { Case- } & \text { Patients with } \\ \text { referent } & \text { nonrespiratory, } \\ & \text { noninfectious, } \\ & \text { nonneoplastic } \\ & \text { diseases, con- } \\ & \text { trolled for age } \\ & \text { and smoking }\end{array}$

Male self-

employed,

butcher's shops

Male self-

employed,

butcher's shops

Male skilled

butchers in

butcher's shops

Male skilled

butchers in

butcher's shops

Male skilled

slaughterhouse

workers

Male skilled

slaughterhouse

workers

Male unskilled

slaughterhouse workers

Male unskilled

slaughterhouse

workers

$\begin{array}{ll}\begin{array}{l}\text { Historical } \\ \text { prospective }\end{array} & \begin{array}{l}\text { Total employed } \\ \text { male population }\end{array} \\ \begin{array}{l}\text { Historical } \\ \text { prospective }\end{array} & \begin{array}{l}\text { Total employed } \\ \text { male population }\end{array} \\ \begin{array}{l}\text { Historical } \\ \text { prospective }\end{array} & \begin{array}{l}\text { Total employed } \\ \text { male population }\end{array} \\ \begin{array}{l}\text { Historical } \\ \text { prospective }\end{array} & \begin{array}{l}\text { Total employed } \\ \text { male population }\end{array} \\ \begin{array}{l}\text { Historical } \\ \text { prospective }\end{array} & \begin{array}{l}\text { Total employed } \\ \text { male population }\end{array} \\ \begin{array}{l}\text { Historical } \\ \text { prospective }\end{array} & \begin{array}{l}\text { Total employed } \\ \text { male population }\end{array} \\ \begin{array}{l}\text { Historical } \\ \text { prospective }\end{array} & \begin{array}{l}\text { Total employed } \\ \text { male population }\end{array} \\ \begin{array}{l}\text { Historical } \\ \text { prospective }\end{array} & \begin{array}{l}\text { Total employed } \\ \text { male population }\end{array}\end{array}$

17

SMR

30

$\left.\begin{array}{r}159 \\ 175\end{array}\right\}$

9

SMR

5

SMR

253

148

85

15

SMR

173

$151)$

159

21

SMR

16

SMR

85

100

prospective male population

35

SMR

$109)$

Fox et al 1982 (2)
National incidence
data Sweden,
1961 - 973

National incidence

data, Sweden,

1961-1973

National incidence

data, Sweden,

1961-1973

Other males

in slaughter-

houses

Male butchers

in slaughter-

houses

Other male

butchers

Hogstedt et al 1983 (9)

National incidence data, Male butchers Sweden, 1974-1979 in slaughter-

houses

\begin{tabular}{ll} 
Historical & Total male \\
prospective & $\begin{array}{l}\text { population, } \\
\text { controlled } \\
\text { for age and } \\
\text { region }\end{array}$ \\
\hline
\end{tabular}

Historical

prospective

Total male

population,

controlled for

age and region

Historical

prospective

Total male

population,

controlled for

age and region

Historical
prospectiv

Total male

population, controlled for

age and region

a To facilitate comparisons the mortality data from Denmark published in references 1 and 2 (Lynge 1982 and Fox et al 1982) are shown under Lynge et al $1983(8)$, and the cancer incidence data from Sweden published in reference 2 (Fox et al 1982) are shown together with those published in reference 9 (Hogstedt et al 1983). 
unity. The 19 estimates are based on 10 to 436 lung cancer cases.

\section{Review of other major surveillance studies}

To supplement the data in table 1 , we reviewed available surveillance studies on occupational cancer. Very few of these, however, were sufficiently detailed to report on lung cancer in butchers.

In the United Kingdom decennial supplement for 1979-1980 and 1982-1983 (16), SMR values of 331 and 176 , respectively, were found for foremen and workers classified as butchers and meatcutters.

In addition to the aforementioned data for men, the Swedish Cancer-Environment Register for 19611973 showed female slaughterhouse workers to have an excess lung cancer risk (RR 1.7) (17). For the period 1971-1984 this register showed an RR of 1.4 for male and 3.0 for female slaughterhouse workers (18).

Death certificate data for Massachusetts, 19711973, showed white male meatcutters aged 20-64 years to have an excess lung cancer mortality [mortality odds ratio (MOR) 175], whereas no excess risk was found for slaughterhouse butchers $(19,20)$. Death certificate data for California, 1959-1961, showed no excess lung cancer risk for butchers (21), neither did a follow-up study of the Canadian labor force, 1965-1973 (22).

A case-referent study of histologically verified lung cancers in Montreal, 1979-1985, showed an OR of 0.7 [ $90 \%$ confidence interval $(90 \% \mathrm{CI}) 0.4$ 1.4] for slaughterers and meat processors when all male patients were included in the analysis and cancer referents were used (23). Men of French origin constituted the largest subgroup (10 out of 11 cases with substantial exposure), and these men had an OR of 2.4 (90\% CI $0.7-7.9)$ when population referents were used. Although smoking was controlled for, the estimated OR values varied depending on whether cancer referents or population referents were used in the analysis (Siemiatycki \& Dewar, personal communication, 1992).

\section{Epidemiologic studies from 1986 to 1989}

Between 1986 and 1989, six studies were published on lung cancer in butchers. Three of the studies cov- ered various members of the Meatcutters' Union in Baltimore (10-12), and the remaining three were from Sweden (13), New Zealand (14), and the United Kingdom (15).

Johnson et al (10-12) identified 28901 members of the Meatcutters' Union in Baltimore between July 1949 and December 1979. These workers were followed until 31 December 1980, when 23364 were alive, 3150 were deceased (of which 200 had a missing death certificate and thus an unknown cause of death), and 2187 were lost to follow-up. In the union files, the members were categorized into the following five areas: abattoirs, meatpacking plants (no slaughtering), meat departments of supermarkets, chicken slaughtering plants, and nonmeat industry (soft drinks, etc). PMR and SMR values were calculated on the basis of mortality data for the general population of the United States.

Table 2 shows that there was a significant excess risk of lung cancer among white male and female union members, particularly concentrated among members who worked in meatpacking plants and supermarkets. Among white men the highest lung cancer rate was, however, found for members working in the nonmeat industry. Among nonwhite men, there was a significant excess risk of lung cancer among abattoir workers, but not among the other workers.

Gustavsson et al (13) undertook a nested case-referent study in a cohort of Swedish men registered as butchers or slaughterhouse workers in the 1960 census. Cases were men who died from squamous cell and small-cell or undifferentiated primary lung cancer in the period 1971-1982. There were 58 eligible cases, of which 13 were excluded for various reasons, the case group therefore being 45 men. Two reference groups were selected from other deceased slaughterhouse workers. The first included 99 men who died of cancer, and the second included a random sample of 100 deceased slaughterhouse workers. Deaths from cancers assumed to be related to exposure to combustion products and deaths from violence or poisoning were excluded.

Information on work, smoking habits, and the like was obtained through questionnaires sent to next-ofkin. Both the cases and the referents had, on the average, worked in four to five different slaughterhouse departments, such as the bleeding area, kill-

Table 2. Proportionate mortality ratios (PMR) and standardized mortality ratios (SMR) for lung cancer among members of The Meatcutters' Union, Baltimore, Maryland (1949-1980). ${ }^{a}$ (NS = not significant, ratios not shown by Johnson et al; $-=$ not shown by Johnson et al; numbers in parentheses = number of lung cancer cases)

\begin{tabular}{|c|c|c|c|c|c|c|c|c|c|c|c|c|}
\hline \multirow[b]{2}{*}{ White women } & \multicolumn{6}{|c|}{ PMR } & \multicolumn{6}{|c|}{ SMR } \\
\hline & $\begin{array}{l}\text { NS } \\
\text { (5) }\end{array}$ & $\begin{array}{c}3.30^{*} \\
(12)\end{array}$ & $\begin{array}{c}2.18^{*} \\
(14)\end{array}$ & $\begin{array}{c}3.81^{*} \\
\text { (3) }\end{array}$ & $\begin{array}{c}\text { NS } \\
(4)\end{array}$ & $\begin{array}{c}2.10^{*} \\
(38)\end{array}$ & $\begin{array}{r}1.41 \\
(5)\end{array}$ & $\begin{array}{c}4.02^{*} \\
(12)\end{array}$ & $\begin{array}{c}1.95^{*} \\
(14)\end{array}$ & $\begin{array}{r}4.56^{*} \\
(3)\end{array}$ & $\begin{array}{r}1.11 \\
(4)\end{array}$ & $\begin{array}{r}1.98^{*} \\
(38)\end{array}$ \\
\hline White men & $\begin{array}{l}\text { NS } \\
(-)\end{array}$ & $\begin{array}{c}1.57^{*} \\
(31)\end{array}$ & $\begin{array}{c}1.27 \\
(46)\end{array}$ & $\begin{array}{l}\text { NS } \\
(-)\end{array}$ & $\begin{array}{c}1.78^{*} \\
(23)\end{array}$ & $\begin{array}{l}1.32^{*} \\
(151)\end{array}$ & $\begin{array}{l}\text { NS } \\
(-)\end{array}$ & $\begin{array}{c}1.88^{*} \\
(31)\end{array}$ & $\begin{array}{c}1.26 \\
(46)\end{array}$ & $\begin{array}{l}\text { NS } \\
(-)\end{array}$ & $\begin{array}{r}2.15^{\star} \\
(23)\end{array}$ & $\begin{array}{l}1.37^{*} \\
(151)\end{array}$ \\
\hline Nonwhite men & - & - & - & - & - & - & $\begin{array}{l}2.1^{*} \\
(23)\end{array}$ & $\begin{array}{c}1.0 \\
(9)\end{array}$ & $\begin{array}{c}1.4 \\
(5)\end{array}$ & $\begin{array}{c}0.6 \\
(3)\end{array}$ & $\begin{array}{l}1.0 \\
(11)\end{array}$ & $\overline{51)}$ \\
\hline
\end{tabular}

a Taken from references $10-12$.

* $\mathrm{P}<0.05$. 
ing floor, meatcutting department, and smokehouse, and it was not possible to obtain reliable information on length of stay in each department. The excess lung cancer risk among slaughterhouse workers could not be attributed to specific departments, but meat cutting was associated with low risk (OR 0.36 and 0.45 ). The expected association between tobacco smoking and lung cancer was found, as all cases were smokers or ex-smokers.

The investigation of Reif et al from New Zealand (14) was a case-referent study based on the New Zealand Cancer Register. It covered 19904 male cancer patients aged 20 years or more at the time of diagnosis in 1980-1984. For each type of cancer the other cancer cases were used as referents. Of the 4224 lung cancer cases, 135 had indicated meat worker as their latest occupation. The overall OR for lung cancer in meat workers was 1.30 [95\% confidence interval $(95 \% \mathrm{CI}) 1.06-1.58$ ]. The OR was 2.94 (95\% CI $0.72-12.02)$ for the age group 2039 years and $1.64(95 \% \mathrm{CI} 1.26-2.15)$ for the age group 20-64 years. Analysis for different types of slaughterhouse work was not possible.

Coggon et al (15) studied a cohort of 1610 male slaughterhouse workers from three companies followed until 1986. Recruitment to the cohort started in 1946 in company A (431 workers), in 1952 in company B (160 workers), and in 1955 in company C (1019 workers). By the end of 1971, all of the workers in the cohort had worked for at least six months with live animals or meat. In the study period, 271 workers died, corresponding to an overall SMR of 86 . Forty-two men died from lung cancer, for which the main results are presented in table 3 . Lung cancer was high among workers who had worked with warm meat, particularly among workers first exposed to warm meat at least 10 years earlier.

Danish survey on the work environment and health status of slaughterhouse workers

A cross-sectional survey of slaughterhouse workers was undertaken in Denmark in 1982. The survey was based on questionnaires from 4828 workers $(82 \%$ men, $83 \%$ response rate) from each of the 147 plants in the Danish slaughterhouse and meat industries. The participants provided information on symptoms, health problems, and work conditions, as well as on sociodemographic data $(24-25)$.

The respondents worked in 70 different departments and used 75 different kinds of equipment. On the basis of this information, 81 specific jobs were constructed. The following exposures are considered relevant for lung cancer: warm meat (slaughterline, intestine department, etc), fumes from plastic materials (meat packaging), combustion products (smokehouse), nitrite (production of sausages and other cold cuts, etc), and job strain [defined as a combination of high work pace and low influence $(26,27)]$. Job strain was measured in two ways: through classification of jobs and on the basis of the individual worker's responses regarding work pace, monotony, influence, degree of freedom, and the like. The prevalence of these exposures in Danish slaughterhouses in 1982 is shown in table 4. One-fourth of the women, but only $4 \%$ of the men, worked with meat packing. The other exposures were not particularly widespread. About $60 \%$ of the female and male workers were exposed to high job strain, measured as the combination of high work pace and low influence or control.

The Danish survey further showed almost all workers to be below the age of 40 years when they started work in the slaughterhouses, and many workers left the industry before reaching the age of 60 years because of the tough work conditions. Hardly any slaughterhouse workers remained in the industry until the legal retirement age of 67 years (28).

Furthermore, the Danish survey sheds light on the reported difference in lung cancer risk between skilled and unskilled slaughterhouse workers in Den-

Table 3. Lung cancer mortality among 1610 men employed in three British meat companies. ${ }^{\text {a }}$ (SMR = standardized mortality ratio, $95 \% \mathrm{Cl}=$ confidence interval)

\begin{tabular}{lrrr}
\hline & $\begin{array}{c}\text { Number } \\
\text { of lung } \\
\text { cancer } \\
\text { deaths }\end{array}$ & SMR & $95 \% \mathrm{Cl}$ \\
\cline { 2 - 4 } & & & \\
Company & 13 & 148 & $79-253$ \\
$\quad$ A & 4 & 91 & $25-234$ \\
B & 25 & 135 & $88-200$ \\
C & 42 & 133 & $96-179$ \\
$\quad$ Total & & & \\
Exposure & 2 & 101 & $12-365$ \\
$\quad$ Live animals & 22 & 184 & $115-279$ \\
Warm meat & 16 & 142 & $81-231$ \\
Chilled meat & 4 & 69 & $19-176$ \\
$\quad$ Bacon process or products & & & \\
Time since first exposure & & & \\
to warm meat & & 0 & $0-491$ \\
$\quad<5$ years & - & 144 & $17-520$ \\
$5-9$ years & 2 & 246 & $123-441$ \\
10-19 years & 11 & 181 & $83-343$ \\
$\geq 20$ years & 9 & & \\
\hline
\end{tabular}

a Taken from reference 15 .

Table 4. Prevalence of certain exposures in the Danish slaughterhouse and meat industry, 1982.a

\begin{tabular}{lcc}
\hline Exposures & $\begin{array}{c}\text { Men } \\
(\mathrm{N}=3730) \\
(\%)\end{array}$ & $\begin{array}{c}\text { Women } \\
(\mathrm{N}=1036) \\
(\%)\end{array}$ \\
\hline Work with warm meat & 22.2 & 6.9 \\
Work with meat packing & 4.3 & 25.0 \\
Work in smokehouse & 0.7 & 0.3 \\
Work in sausage department & 5.4 & 9.8 \\
High job strain (job classification) & 58.8 & 59.5 \\
High job strain (individual \\
classification)
\end{tabular}

a Taken from references 24 and 28. 
mark. This difference is puzzling because skilled and unskilled workers in Danish slaughterhouses work in the same departments with very similar job tasks. Table 5 shows the incidence of lung cancer, 19701980 , among men working in butcher's shops, slaughterhouses, and agriculture (29), together with selected results from the slaughterhouse survey. The skilled workers had worked twice as long, typically all their adult life, in the slaughterhouses as the unskilled workers had. A large part of the unskilled workers were recruited from agriculture, where the incidence of lung cancer is low (SIR 40-72). About two-thirds of the workers in both groups were smokers, and the average age in both groups was $38-39$ years.

\section{Evaluation of the evidence and hypotheses}

Do butchers have an increased risk of lung cancer?

As it appears, many studies support the hypothesis that there is an excess risk of lung cancer among butchers $(1-4,6,8-12,14-20)$, while other studies do not $(5,7,21-23,30)$. Two of the negative investigations: the Washington state study $(5,30)$ and the California study (21) are PMR studies based on death certificates. In these investigations nondifferential misclassification of exposure (occupation) may have caused bias towards the null. The problems with the validity of occupational data on death certificates are mentioned explicitly in both papers $(21$, page $5-$ $6 ; 30$, page 1). The negative study by Vena et al (7) was a case-referent study using hospital referents. A possible excess risk from other causes of death or diseases among butchers could thus explain the negative outcome of all three of these studies. The large and well-conducted case-referent study from Montreal (23) does in fact indicate that the choice of referents is decisive. As has already been mentioned, this study showed an OR of 0.7 for lung cancer among butchers when cancer referents were used and an OR of 2.4 when French population referents were used. The last negative study of lung cancer in butchers (22) was a follow-up study, but the butchers seemed, from the sparse data reported, to constitute a relatively small group.

Methodological problems may thus explain the negative findings in some of the studies of lung cancer in butchers. It should be kept in mind that negative results in surveillance studies are common. The authors of one of the negative studies pointed out (22, page 39) that several established occupation-cancer associations were not found in their study.

Compared with the negative studies, the positive studies tend to be of better quality (ie, larger number of cases, small dropout rate, reliable registers, knowledge of the size of the population at risk, and longterm follow-up). An overall evaluation of the literature thus leads to the conclusion that butchers in general have an excess risk of lung cancer.

Finally it should be pointed out that, although the slaughterhouse industry is homogeneous, workplace exposures may have varied between butchers in different geographic areas and in different time periods. Such differences may explain some of the divergences in the study results.

\section{Is the excess risk possibly caused by exposures in the work environment?}

The most important question with respect to possible occupational etiologic factors is, obviously,

Table 5. Standardized incidence ratios (SIR) of lung cancer in 1970-1980 among Danish men employed in butcher's shops, slaughterhouses, and agriculture in 1970 . $^{a}$ For slaughterhouse workers supplementary information from the Danish slaughterhouse study, 1982, is included. ${ }^{\mathrm{b}}$

\begin{tabular}{|c|c|c|c|c|c|c|}
\hline Employment & $\begin{array}{l}\text { Number } \\
\text { of } \\
\text { lung } \\
\text { cancer } \\
\text { cases }\end{array}$ & SIR & $\begin{array}{c}\text { Average } \\
\text { age } \\
\text { (years) }\end{array}$ & $\begin{array}{c}\text { Average } \\
\text { time as } \\
\text { slaughter- } \\
\text { house- } \\
\text { worker } \\
\text { (years) }\end{array}$ & $\begin{array}{c}5 \text { years } \\
\text { or more } \\
\text { in agri- } \\
\text { culture } \\
(\%)\end{array}$ & $\begin{array}{c}\text { Current } \\
\text { smokers } \\
(\%)\end{array}$ \\
\hline \multicolumn{7}{|l|}{ Butcher's shop } \\
\hline $\begin{array}{l}\text { Self-employed } \\
\text { Skilled butcher }\end{array}$ & $\begin{array}{l}55 \\
20\end{array}$ & $\begin{array}{l}167^{\star} \\
179^{*}\end{array}$ & $\begin{array}{l}\cdots \\
\cdots\end{array}$ & $\begin{array}{l}\cdots \\
\cdots\end{array}$ & $\begin{array}{l}\cdots \\
\cdots\end{array}$ & $\begin{array}{l}\cdots \\
\cdots\end{array}$ \\
\hline \multicolumn{7}{|l|}{ Slaughterhouse } \\
\hline $\begin{array}{l}\text { Skilled worker } \\
\text { Unskilled worker }\end{array}$ & $\begin{array}{l}44 \\
60\end{array}$ & $\begin{array}{c}165^{\star} \\
99\end{array}$ & $\begin{array}{l}38.1 \\
38.8\end{array}$ & $\begin{array}{l}20.1 \\
10.5\end{array}$ & $\begin{array}{r}1.5 \\
40.0\end{array}$ & $\begin{array}{l}68 \\
63\end{array}$ \\
\hline $\begin{array}{l}\text { Unskilled worker, } \\
\text { agriculture }\end{array}$ & 191 & $72^{\star}$ & $\cdots$ & . & . & $\cdots$ \\
\hline \multicolumn{7}{|l|}{ Farmer } \\
\hline $\begin{array}{l}\text { Small-size farms } \\
\text { Middle-size farms }\end{array}$ & $\begin{array}{l}206 \\
353\end{array}$ & $\begin{array}{l}41^{\star} \\
40^{\star}\end{array}$ & $\begin{array}{l}\cdots \\
\cdots\end{array}$ & $\begin{array}{l}\cdots \\
\cdots\end{array}$ & $\begin{array}{l}\cdots \\
\cdots\end{array}$ & $\begin{array}{l}\cdots \\
\cdots\end{array}$ \\
\hline
\end{tabular}


whether or not the smoking habits of butchers can account for their lung cancer risk. The significance of tobacco smoking as a confounder in studies on occupation and lung cancer has been discussed extensively. Even though the importance of tobacco smoking as a confounder is often overestimated, it is generally agreed that excess relative risks for lung cancer in the range of 1.0 to 2.0 may be due to a higher proportion of smokers in the study group than in the population at large. The relative risks of lung cancer among butchers fall within this range.

When individual smoking data are missing, the following indirect control methods can be used (3133): (i) analysis of other tobacco-related diseases in the study population, (ii) adjustment for presumed differences in smoking habits between the exposed and unexposed populations, (iii) comparison with an internal, unexposed population, and (iv) analysis of a possible exposure-response relationship.

The lung cancer risk among Swedish butchers for the period 1961-1979 decreased from an SIR of 176 to an SIR of 133 (95\% CI 100-179) when adjustment was made for smoking determined on the basis of a survey of smoking habits $(34,35)$. About two-thirds of Danish slaughterhouse workers were smokers (table 5), and this figure is equivalent to that of other occupational groups in Denmark $(36,37)$. In Great Britain, the "current smoking ratio" for butchers and meatcutters in 1972 was 99 , indicating smoking habits very close to the average for all men (16).

Individual smoking data were not available in the study by Coggon et al (15). However, an SMR of 86 was found for ischemic heart disease, and an SMR of 72 was found for nonmalignant, respiratory diseases. Furthermore, the excess risk was concentrated among workers exposed to warm meat and arose 10 years after the first exposure.

Reif et al (14) controlled indirectly for tobacco smoking with data from a national survey which showed the number of current smokers among food and beverage workers to be $47 \%$ compared with $38 \%$ on the average among employed men. Assuming slaughterhouse workers to have the same smoking habits as workers in the food and beverage industry, Reif et al expected an RR of 1.20 due to smoking alone. If this assumption is valid, tobacco smoking thus largely explains the excess risk of lung cancer among New Zealand slaughterhouse workers.

Vena et al (7) had individual data on smoking in their hospital-based case-referent study, where adjustment for smoking reduced the OR from 1.1 to 1.0. Smoking habits were adjusted for in the OR of 0.7 for all slaughterers and meat processors in Montreal, and in the OR of 2.4 for the largest subgroup of French origin (23).

In the studies by Johnson et al (10-12) white male nonmeat workers had a higher lung cancer mortality than the four groups of slaughterhouse workers. An inverse pattern was found for white women and nonwhite men (table 2). It is thus difficult to draw conclusions regarding confounding from smoking in these studies.

Indirect adjustment for tobacco smoking thus eliminated the excess lung cancer risk among New Zealand butchers, moderated the excess risk among Swedish butchers, but did not affect the excess risk for butchers in the United Kingdom or Denmark. Direct adjustment for tobacco smoking eliminated the marginal excess lung cancer risk for hospital patients from New York, but did not eliminate the excess lung cancer risk for slaughterhouse workers of French origin in Montreal.

While it must be assumed that tobacco smoking can lead to a positive bias for estimated lung cancer risk, there are several other factors that probably have the opposite effect. First, when butchers are compared with the general population, carcinogens occurring in other workplaces, but not in slaughterhouses, are negative confounders. Second, butchers are less exposed to "city life" as slaughterhouses are located mostly in small towns. Third, none of the studies have taken primary selection and recruitment to the work into account. Table 5 shows the Danish lung cancer SIR values for 1970 - 1980, which are 40 for farmers, 72 for agricultural workers, 99 for unskilled slaughterhouse workers, and 165 for skilled workers. Thus a pattern emerges that almost resembles an exposure-response relationship. Fourth, as has already been mentioned, there is reason to believe that a considerable number of slaughterhouse workers leave the industry at an early age due to the stressfulness of the work. Thus, at a certain point in time (eg, on a census date), many men with a background in slaughterhouse work will be registered under other occupations or as economically inactive. The same is true for their subsequent lung cancers when such populations are followed-up. This secondary selection will also cause a negative bias. Fifth, the terms "butcher" and "slaughterhouse worker" are proxies for unknown exposures which may affect only a proportion of the workers. This potential dilution effect also causes negative bias. Finally, nondifferential misclassification of diseases and occupation may occur in certain studies and will create bias towards the null.

It is not possible to quantify and weigh the various types of potential biases. But it is our evaluation that butchers have an excess risk of lung cancer which exceeds the risk attributable to confounding or bias.

\section{Which exposures in the work environment could possibly explain the excess risk?}

Papilloma virus hypothesis. Pegum (38) presented the hypothesis that papilloma virus could be a cause of lung cancer among butchers. He observed that butchers often have viral warts and that human wart viruses, which cause benign papillomas of the skin, 
have also been associated with malignant changes (39). Both Johnson (12) and Gustavsson et al (13) mentioned the papilloma virus hypothesis, and $\mathrm{Cog}$ gon et al (15) stated that "if there is a hazard, infection by a papilloma virus would seem the most likely cause [p 188]."

The prevalence of virus warts among slaughterhouse workers, including poultry slaughterhouse workers (40-45), has been assessed in several studies and shows the following patterns: (i) the prevalence of virus warts among slaughterhouse workers is generally high, $24-47 \%$; (ii) in studies which allow comparison with unexposed groups, there is a prevalence ratio of about 3 ; (iii) the high prevalence of virus warts is found in all departments of slaughterhouses, but one study (45) found a higher prevalence $(47 \%)$ among "meat handlers" than among "non meat handlers," (31\%).

The warts may derive from infection with various types of human papilloma virus (40). The slaughtered animals may act as vectors for the infection from one worker to another. It is probable that workers with wet hands, and with skin traumas on their hands, are the most susceptible to infection. These conditions are common in departments where workers handle warm meat, slaughterline and intestine departments, and in many other areas of the slaughterhouses. Hence this is an exposure that affects all types of jobs in the slaughterhouse industry, but in particular the workers who are in direct contact with meat. This exposure pattern is consistent with the lung cancer pattern found in epidemiologic studies.

HPV-DNA (human papilloma virus-deoxyribonucleic acid) sequences of various types have been detected in lung cancer tissue from many patients, primarily in cases of squamous-cell carcinomas (4652). Although the types of human papilloma virus which have so far been detected in butchers' warts and in lung cancer tissue do not overlap, the papilloma virus hypothesis cannot be dismissed on the basis of the results of existing studies.

Nitrite hypothesis. Nitrite has been used for the curing of sausage and other meat products, and some studies $(53,54)$ have suggested that the formation of nitrosamines in meat has a possible carcinogenic effect on people who eat nitrite-treated meat. In one epidemiologic study Gustavsson et al (13) wrote that use of "nitrite should not result in exposure by inhalation among the slaughterhouse workers [p 519]," and Coggon et al (15) stated that very few workers were employed in meat preservation. In the Danish survey (table 4 ), only $5 \%$ of the men and $10 \%$ of the women worked in the sausage department, where preservation with nitrite took place up until the 1960s. If exposure to nitrite causes lung cancer, there should be a very high risk among the few exposed slaughterhouse workers. Such an excess risk in a small, clearly defined subgroup would probably have been noted by alert clinicians or would have shown up in at least one of the epidemiologic studies; however, such a pattern has not been observed. Thus the nitrite hypothesis is not empirically supported, and in our opinion there is no reason to pursue it.

Incomplete combustion product hypothesis. Exposure to incomplete combustion products, especially polycyclic aromatic hydrocarbons $(\mathrm{PAH})$, generated in smokehouses have been regarded as possible risk factors by several authors. A Swedish study $(13,55,56)$ specifically addressed this hypothesis.

Measurements of PAH and other combustion products in smokehouses (55-57) indicate that smokehouse workers may have been exposed to considerable levels. Incomplete combustion products are considered the cause of an excess lung cancer risk in other occupational groups (58-62).

The Danish survey of slaughterhouse workers found that less than $1 \%$ worked in smokehouses (table 4). Gustavsson et al reported that about $45 \%$ of both cases and referents had worked in smokehouses in their study (13). This significant divergence can have several explanations. The Swedish figures are lifetime prevalences, and the Danish figures are point prevalences. In addition smoked meat has traditionally constituted a larger proportion of meat products in Sweden than in Denmark, and fewer persons have been exposed as the smoking process has been automatized. The proportion of butchers working with meat smoking was small in the United Kingdom study (15) and negligible in the United States study $(10-12)$. Thus we can conclude that exposure to incomplete combustion products is unlikely to explain the excess lung cancer risk among butchers, as (i) the proportion of exposed workers is probably very small in most countries and (ii) none of the epidemiologic studies have supported this hypothesis, including the study by Gustavsson et al (13).

Meatpacking hypothesis. The meatpacking hypothesis was presented by Johnson et al (11). In addition several studies have observed meat wrappers' asthma. During meat wrapping, the plastics are heated when they are shaped, welded, and cut, and fumes are then emitted from the thermal decomposition of the plastics. The materials used in Baltimore, in the United States, included polystyrene, polyethylene, rubber hydrochloride, cellophane, and polyvinyl chloride (PVC). When PVC is heated, benzene, phthalic anhydride and phthalates, among other substances, are formed. Benzene is leukemogenic in humans, and the other two products are carcinogenic in animals (11).

In the Danish survey of slaughterhouse workers $4 \%$ of the men and $25 \%$ of the women worked with meatpacking and wrapping (table 4). Among the 
Swedish men in the study by Gustavsson et al (13), the lifetime prevalence of this work was about $15 \%$ for both the cases and the referents. Meat packing was not mentioned in the study by Coggon et al (table 3).

The meatpacking hypothesis was generated from the findings of Johnson et al that excess lung cancer risks existed for "meatpacking" and "supermarkets." However, Johnson et al also found excess risks for workers probably not exposed to plastics fumes, such as white women in chicken plants (PMR 3.81), white men in the nonmeat reference group (PMR 1.78, SMR 2.63), and nonwhite men in abattoirs (SMR 2.1) (all figures from table 2). Coggon et al (15) found a significant excess risk only among men who worked with warm meat. None of these men worked with meat packing. Gustavsson et al (13) found an OR of 0.9 for men who had worked with meat packing. Reif et al (14) found that only a minority of workers were exposed to PVC decomposition products. This finding is consistent with the work conditions reported for Danish and Swedish butchers. It is thus our evaluation that the empirical support for the meatpacking hypothesis is at present weak.

Work stress hypothesis. Work-related stress has not previously been mentioned in the literature on lung cancer among butchers. However, we believe that it is relevant to consider this issue in view of the increased research into psychosocial stressors, stress, and cancer. Stress is hypothesized to increase cancer risk through changes in immune functions or in the regulation of cell growth (63-67).

Several Danish studies have shown that slaughterhouse workers are particularly exposed to stressors in the workplace and that they have a high incidence of psychosomatic disorders $(24,25,68-71)$. In the 1982 slaughterhouse survey about $60 \%$ of the workers were exposed to job strain, compared with an estimated $16 \%$ of women and $6 \%$ of men in the total Danish work force (72). The high level of job strain in slaughterhouses can be regarded as a result of the introduction of "scientific management" in the 1950s and $1960 \mathrm{~s}$.

The possible influence of stressors on lung cancer risk has, to our knowledge, been studied only in very few populations.

Marmot and his co-workers found civil servants of low status to have a higher prevalence of job strain (73) and subsequently to have a higher lung cancer risk (74) than civil servants of high status. The lung cancer data were controlled for differences in smoking habits.

Hatch et al (67) used proximity to the plant as a surrogate for stress in people living near the Three Mile Island nuclear power plant. Before the accident in 1979 , the lung cancer incidence was slightly higher among people living close to the reactor $(0-6 \mathrm{~km})$ than among those living further away $(>12 \mathrm{~km})(\mathrm{OR}$ 1.2). This difference was increased after the accident (OR 1.7). The analysis controlled for potential confounders. The OR values for lung cancer mortality were, however, 1.4 for the period before the accident and 1.3 for the period after. It is thus difficult to conclude whether the increased incidence close to the plant after the accident was a screening effect or was related to stress.

Other related studies have not included variables comparable to job strain or other job stressors (75, 76) or have not concerned specific data on lung cancer risk (77).

The well-documented stressful work of slaughterhouse workers makes it relevant to consider this factor also in relation to lung cancer risk. It should be pointed out, however, that the observation of an excess lung cancer risk among butchers in England and Wales already around the time of the 1951 census points to etiologic factors which have persisted in butchers' work environments for a long time.

\section{Concluding remarks}

On the basis of our review, we conclude that there is evidence for excess lung cancer risk among butchers, at least in part due to exposures in the work environment. However, it is difficult, from the studies reviewed, to pinpoint the probable etiologic factors. Among the exposures mentioned in the literature, we believe, however, that we can dismiss incomplete combustion products, fumes from meatpacking materials, and nitrite used for the preservation of meat. One or more of these exposures may have caused individual cases of lung cancer in butchers, but none of them can explain the pattern and the level of the observed lung cancer risk. Hence two hypotheses remain, each of which should be examined more closely in future research, namely, the human papilloma virus hypothesis and the work stress hypothesis.

It is crucial that future studies on lung cancer in butchers be more specific on two points in particular. First, carefully selected reference groups should be used to supplement the national population, other deaths, or other cancers which have been used so far. Second, tobacco smoking should, wherever possible, be determined on an individual level.

\section{References}

1. Lynge E. The Danish occupational cancer study. In: Prevention of occupational cancer - international symposium. Geneva: ILO, 1982:557-68. (Occupational safety and health series; no 46.)

2. Fox AJ, Lynge E, Malker H. Lung cancer in butchers. Lancet 1982;1:165-6.

3. Griffith GW. Lung cancer in butchers. Lancet 1982; $1: 399$.

4. Doerken H, Rehpenning W. Lung cancer in butchers. Lancet 1982;1:561. 
5. Milham S. Lung cancer in butchers. Lancet 1982;1: 690.

6. Johnson ES, Fischman HR. Cancer mortality among butchers and slaughterhouse workers. Lancet 1982;1: $913-4$.

7. Vena JE, Byers T, Swanson M, Cookfair D. Lung cancer in butchers? Lancet 1982;2:713.

8. Lynge E, Andersen O, Kristensen TS. Lung cancer in Danish butchers. Lancet 1983;1:527-8.

9. Hogstedt C, Carstensen J, Svensson E, Weiner J. Luftvägscancer hos slaktare och bagare - bearbetningar av cancermiljöregistret och rökvaneundersökningen [Respiratory cancer in butchers and bakers analyses of the Cancer-Environment Register and the smoking habit survey]. Hygiea 1983;92:121.

10. Johnson ES, Fischman HR, Matanoski GM, Diamond E. Cancer mortality among white males in the meat industry. J Occup Med 1986;28:23 - 32.

11. Johnson ES, Fischman HR, Matanoski GM, Diamond E. Occurrence of cancer in women in the meat industry. Br J Ind Med 1986;43:597-604.

12. Johnson ES. Mortality among nonwhite men in the meat industry. J Occup Med 1989;31:270-2.

13. Gustavsson P, Fellenius E, Hogstedt C. Possible causes of increased lung cancer incidence among butchers and slaughterhouse workers. Scand J Work Environ Health 1987;13:518-23.

14. Reif JS, Pearce NE, Fraser J. Cancer risks among New Zealand meat workers. Scand J Work Environ Health 1989;15:24-9.

15. Coggon D, Pannett B, Pippard EC, Winter PD. Lung cancer in the meat industry. $\mathrm{Br} \mathrm{J}$ Ind Med 1989;46: 188-91.

16. Office of Population Censuses and Surveys. Occupational mortality: the Registrar General's decennial supplement for Great Britain, 1979-80, 1982-83. London: Her Majesty's Stationary Office, 1986.

17. Malker $\mathrm{H}$, Weiner J. Cancer-miljöregistret. Exempel på utnyttjande av registerepidemiologi inom arbetsmiljöområdet [The Cancer-Environment Register: an example of the use of registers in occupational epidemiology]. Stockholm: Arbetarskyddsverket, 1984. (Arbete och hälsa 1984:9.)

18. Ahlbom A, Gerhardsson M, Hogstedt C, Lundberg I, Plato N, Steineck G, et al. Yrke och cancer. En analys baserad på cancer-miljöregistret 1970 [Occupation and cancer: an analysis based on the Cancer-Environment Register 1970]. Stockholm: Institutet för miljömedicin, Karolinska institutet, 1990. (IMM-rapport 2/90.)

19. Dubrow R, Wegman DH. Occupational characteristics of white male cancer victims in Massachusetts 19711973. Cincinnati, OH: National Institute for Occupational Safety and Health, 1982.

20. Dubrow R, Wegman DH. Cancer and occupation in Massachusetts: a death certificate study. Am J Ind Med 1984;6:207-30.

21. Petersen GR, Milham S. Occupational mortality in the state of California 1959-1961. Cincinnati, OH: National Institute for Occupational Safety and Health, 1980. (DHEW (NIOSH) publication; no 80-104.)

22. Howe GR, Lindsay JP. A follow-up study of a ten-percent sample of the Canadian labor force: I. cancer mortality in males, 1965-73. JNCI 1983;70:37— 44.

23. Siemiatycki J. Risk factors for cancer in the workplace. Boca Raton: CRC Press Inc, 1991.

24. Kristensen TS, Christensen FL. Slagteriarbejde [Slaughterhouse work]. Copenhagen: Arbejdsmiljøfondet, 1983.

25. Kristensen TS. Sickness absence and work strain among Danish slaughterhouse workers: an analysis of absence from work regarded as coping behaviour. Soc Sci Med 1991;32:15-27.

26. Karasek RA. Job demands, job decision latitude, and mental strain: implications for job redesign. Adm Sci Q 1979;24:285-308.

27. Karasek R, Theorell T. Healthy work: stress, productivity, and the reconstruction of working life. New York, NY: Basic Books, Inc, 1990.

28. Kristensen TS. Slagteriarbejdernes arbejdsmiljø og helbred. I. Beskrivelse af baggrund, metode og population [Working conditions and health of slaughterhouse workers: I. description of background, methods and population]. Ugeskr Læger 1984;146:3947-51.

29. Lynge E, Thygesen L. Occupational cancer in Denmark: cancer incidence in the 1970 census population. Scand J Work Environ Health 1990;16 suppl 2:1-35.

30. Milham S. Occupational mortality in Washington state 1950 - 1979. Cincinnati, OH: National Institute for Occupational Safety and Health, 1983.

31. Axelson $O$, Steenland $K$. Indirect methods of assessing the effects of tobacco use in occupational studies. Am J Ind Med 1988;13:105-18.

32. Siemiatycki J, Wacholder S, Dewar R, Wald L, Begin D, Richardson L, et al. Smoking and degree of occupational exposure: are internal analyses in cohort studies likely to be confounded by smoking status? Am J Ind Med 1988;13:59-69.

33. Steenland K, Beaumont J, Halperin W. Methods of control for smoking in occupational cohort mortality studies. Scand J Work Environ Health 1984;10: $143-9$.

34. Carstensen JM, Pershagen G, Eklund G. Smoking-adjusted incidence of lung cancer among Swedish men in different occupations. Int J Epidemiol 1988;17: $753-8$

35. Carstensen J. Occupation, smoking and lung cancer: cohort study based on Swedish register data. Stockholm: Karolinska Institute and Hospital, 1987.

36. Olsen JH, Borch-Johnsen K, Roed-Petersen B. Rygevaner og erhvervsmæssig beskæftigelse [Smoking habits and occupation]. Ugeskr Læger 1985;147:2788--92.

37. Nielsen PE, Zacho J, Olsen JA, Olsen CA. Endringer $i$ danskernes rygevaner 1970-1987 [Changes of smoking habits among Danes 1970-1987]. Ügeskr Læger 1988;150:2229-33.

38. Pegum JS. Lung cancer in butchers. Lancet 1982;1: 561.

39. Orth G, Jablonska S, Jarzabek-Chorzelska M, Obalek S, Rzesa G, Favre M, Croissant O. Characteristics of the lesions and risk of malignant conversion associated with the type of human papillomavirus involved in epidermodysplasia verruciformis. Cancer Res 1979; 39:1074-82.

40. Orth G, Jablonska S, Favre M, Croissant O, Obalek $\mathrm{S}$, Jarzabek-Chorzelska M, Jibard N. Identification of papillomaviruses in butchers' warts. J Invest Dermatol $1981 ; 76: 97-102$.

41. Litt JZ. Warts in meat-cutters. Arch Dermatol 1969; 100:773.

42. Mergler D, Vezina N, Beauvais A. Warts among workers in poultry slaughterhouses. Scand J Work Environ Health $1982 ; 8$ suppl $1: 180-4$

43. de Peuter M, de Clercq B, Minette A, la Chapelle JM An epidemiological survey of virus warts of the hands among butchers. Br J Dermatol 1977;96:427-31.

44. Taylor SWC. A prevalence study of virus warts on the hands in a poultry processing and packing station. J Soc Occup Med 1980;30:20-3.

45. Wall LM, Oakes D, Rycroft RJG. Virus warts in meat handlers. Contact Dermatitis 1981;7:259-67.

46. Stremlau A, Gissmann L, Ikenberg H, Stark M, Bannasch $P$, Hausen HZ. Human papillomavirus type 16 related DNA in an anaplastic carcinoma of the lung. Cancer 1985;55:1737-40.

47. Syrjänen KJ, Syrjänen SM. Human papillomavirus DNA in bronchial squamous cell carcinomas. Lancet 1987;1:168-9. 
48. Berjui-Thivolet F, Liagre N, Chignol MC, Chardonnet Y, Patricot LM. Detection of human papillomavirus DNA in squamous bronchial metaplasia and squamous cell carcinomas of the lung by in situ hybridization using biotinylated probes in paraffin-embedded specimens. Hum Pathol 1990;21:111-6.

49. Bejui-Thivolet F, Chardonnet Y, Patricot LM. Human papillomavirus type 11DNA in papillary squamous cell lung carcinoma. Virchows Arch (A) 1990;417:45761.

50. Kashima HK, Kessis T, Mounts P, Shah K. Polymerase chain reaction identification of human papillomavirus DNA in $\mathrm{CO}_{2}$ laser plume from recurrent respiratory papillomatosis. Otolaryngol Head Neck Surg 1991;104:191-5.

51. Yousem SA, Ohori NP, Sonmez-Alpan E. Occurrence of human papillomavirus DNA in primary lung neoplasms. Cancer 1992;69:693-7.

52. DiLorenzo TP, Tamsen A, Abramson AL, Steinberg BM. Human papillomavirus type 6a DNA in the lung carcinoma of a patient with recurrent laryngeal papillomatosis is characterized by a partial duplication. J Gen Virol 1992;73:423-8.

53. Sen NP, Miles WF, Donaldson B, Panalaks T, Iyengar JR. Formation of nitrosamines in a meat curing mixture. Nature 1973;245:104-5.

54. Sen NP, Donaldson B, Charbonneau C, Miles WF. Effects of additives on the formation of nitrosamines in meat curing mixtures containing spices and nitrite. J Agric Food Chem 1974;22:1125-30.

55. Gustavsson P, Fellenius E, Hogstedt C. Lungcancer bland slaktare och charkuterister [Lung cancer among butchers and meatcutters]. Stockholm: Arbetarskyddsverket, 1988. (Arbete och hälsa 1988:7.)

56. Svensson E, Gustavsson P, Hogstedt C, Malker H, Ulfvarson U. Rapport till Arbetarskyddsfonden angående projektet: projektering av studie av cancersjuklighet bland slakterianställda [Report to The Work Environment Fund regarding the project: planning a study on cancer incidence among slaughterhouse workers]. Stockholm: Arbetarskyddsfonden, 1984.

57. Nordholm L, Espensen I-M, Jensen HS, Holst E. Polycyclic aromatic hydrocarbons in smokehouses. Scand J Work Environ Health 1986;12:614-8.

58. Gustavsson P, Gustavsson A, Hogstedt C. Excess mortality among Swedish chimney sweeps. Br J Ind Med 1987;44:738 -43 .

59. Hansen ES. Mortality from cancer and ischemic heart disease in Danish chimney sweeps: a five-year followup. Am J Epidemiol 1983;117:160-4.

60. Doll R, Vessey P, Beasley RWR, Buckley AR, Fear EC, Fisher REW, et al. Mortality of gas workers final report of a prospective study. $\mathrm{Br} \mathrm{J}$ Ind Med 1972;29:394-406.

61. Hurley JF, Archibald RM, Collings PL, Fanning DM, Jacobsen M, Steele RC. The mortality of coke workers in Britain. Am J Ind Med 1983;4:691-704.
62. Redmond CK. Cancer mortality among coke oven workers. Environ Health Perspect 1983;52:66-73.

63. Kennedy S, Kiecolt-Glaser JK, Glaser R. Immunological consequences of acute and chronic stressors: mediating role of interpersonal relationships. Br J Med Psychol 1988;61:77-85.

64. Cox T. Psychobiological factors in stress and health. In: Fisher S, Reason J, ed. Handbook of life stress, cognition and health. New York, NY: John Wiley and Sons, 1988:603-28.

65. Kaplan HB. Social psychology of the immune system: a conceptual framework and review of the literature. Soc Sci Med 1991;33:909-23.

66. Janerich DT. Can stress cause cancer? Am J Public Health $1991 ; 81: 687-8$.

67. Hatch MC, Wallenstein S, Beyea J, Nieves JW, Susser M. Cancer rates after the Three Mile Island nuclear accident and proximity of residence to the plant. Am J Public Health 1991;81:719-24.

68. Hansen NS. Effects on health of monotonous, forcedpace work in slaughterhouses. J Soc Occup Med 1982; $32: 180-4$.

69. Kristensen TS. Slagteriarbejdernes arbejdsmiljø og helbred: IV. stress, træthed og psykosomatiske symptomer [Working conditions and health of slaughterhouse workers: IV. stress, fatigue and psychosomatic symptoms]. Ugeskr Læger 1985;147:1713-20.

70. Arbejdsmiljøgruppen af 1972. Arbejdsmiljøundersøgelsen [The work environment study]. Copenhagen: Arbejdsmiljøgruppen, 1974.

71. Hansen EJ, Geckler S, Rasmussen MK. Fordelingen af levekårene; bind III [The distribution of living conditions; vol III]. Copenhagen: The Danish National Institute of Social Research, 1980.

72. Olsen O, Kristensen TS. Impact of work environment on cardiovascular diseases in Denmark. J Epidemiol Community Health 1991;45:4-10.

73. Markowe HLJ, Marmot MG, Shipley MJ, Bulpitt CJ, Meade TW, Stirling Y, et al. Fibrinogen: a possible link between social class and coronary heart disease. Br Med J 1985;291:1312—4.

74. Marmot MG, Shipley MJ, Rose G. Inequalities in death - specific explanations of a general pattern? Lancet 1984;1:1003-6.

75. Horne RL, Picard RS. Psychosocial risk factors for lung cancer. Psychosom Med 1979;41:503-14.

76. Joffres M, Reed DM, Nomura AMY. Psychosocial processes and cancer incidence among Japanese men in Hawaii. Am J Epidemiol 1985;121:488-500.

77. Alfredsson L, Spetz C-L, Theorell T. Arbetsmiljö yrke - utnyttjande av sluten vård [Work environment - occupation - use of hospitals]. Stockholm: Statens Offentliga Utredningar, 1984:65-101. (Statens Offentliga Utredningar 1984:41.)

Received for publication: 3 August 1992 